Acta Universitatis Wratislaviensis No 3977

PRAWO CCCXXIX

Wrocław 2019

https://doi.org/10.19195/0524-4544.329.38

\author{
KATARZYNA MAŁYSA-SULIŃSKA \\ ORCID: 0000-0002-6406-8851 \\ Uniwersytet Jagielloński \\ k.malysa-sulinska@uj.edu.pl
}

\title{
Regulacje szczególne dotyczące wydawania decyzji o warunkach zabudowy dla inwestycji kwalifikowanej jako instalacja odnawialnego źródła energii
}

\begin{abstract}
Abstrakt: Przedmiotem artykułu są regulacje szczególne dotyczące wydawania decyzji o warunkach zabudowy dla inwestycji kwalifikowanej jako instalacja odnawialnego źródła energii. Przedstawiono w nim przesłanki, których spełnienie determinuje wydanie przedmiotowej decyzji lokalizacyjnej. Zwrócono również uwagę, iż obowiązująca od dnia 29 sierpnia 2019 roku nowelizacja art. 61 ust. 3 ustawy z dnia 27 marca 2003 roku o planowaniu i zagospodarowaniu przestrzennym, którą wprowadzono wprost odniesienia do instalacji odnawialnego źródła energii, zasadniczo nie zmieniła regulacji obowiązujących w zakresie określania warunków zabudowy i zagospodarowania terenu.
\end{abstract}

Słowa kluczowe: instalacja odnawialnego źródła energii, urządzenie infrastruktury technicznej, przesłanki wydania decyzji o warunkach zabudowy.

\section{Wstęp}

Z dniem 29 sierpnia 2019 roku zaczęła obowiązywać — wprowadzona art. 4 pkt 2 ustawy z dnia 19 lipca 2019 roku o zmianie ustawy o odnawialnych źródłach energii oraz niektórych innych ustaw ${ }^{1}$ - nowelizacja art. 61 ust. 3 ustawy z dnia 27 marca 2003 roku o planowaniu i zagospodarowaniu przestrzennym ${ }^{2}$. Zgodnie z przywołaną zmianą wydanie decyzji o warunkach zabudowy z pominięciem za-

1 Dz.U. z 2019 r. poz. 1524 ze zm. (dalej: u.z.o.z.e.).

2 Dz.U. z 2020 r. poz. 293 (dalej: u.p.z.p.). 
sady dobrego sąsiedztwa oraz dostępu do drogi publicznej dotyczy już nie tylko linii kolejowych, obiektów liniowych i urządzeń infrastruktury technicznej ${ }^{3}$, ale także instalacji odnawialnego źródła energii w rozumieniu art. 2 pkt 13 ustawy z dnia 20 lutego 2015 roku o odnawialnych źródłach energii ${ }^{4}$. Jak wskazano w uzasadnieniu projektu przywołanej ustawy nowelizującej, zmiana ta podyktowana została rozbieżnościami judykatury w zakresie kwalifikowania urządzeń wytwarzających energię ze źródeł odnawialnych do kategorii urządzeń infrastruktury technicznej, o których mowa w art. 61 ust. 3 u.p.z.p. Projektodawcy nowych rozwiązań normatywnych podnieśli przy tym, że przedmiotowa rozbieżność orzecznicza determinuje - w związku z dynamicznym rozwojem branży odnawialnych źródeł energii — konieczność rozszerzenia zakresu regulacji art. 61 ust. 3 u.p.z.p. o instalacje odnawialnych źródeł energii. Jednocześnie - w ich opinii — nowe brzmienie przywołanego powyżej przepisu stanowi potwierdzenie, że urządzenia wytwarzające energię z odnawialnych źródeł nie stanowią urządzeń infrastruktury technicznej5.

W związku z tym przedstawienia wymagają (obowiązujące od dnia 29 sierpnia 2019 roku) regulacje szczególne dotyczące wydawania decyzji o warunkach zabudowy dla inwestycji kwalifikowanej jako instalacja odnawialnego źródła energii. Rozważenia wymaga również, czy wskazana nowelizacja w istocie spełnia założenie ustawodawcy, czy też nie ma uzasadnienia dla jej wprowadzenia do porządku normatywnego.

\section{Inwestycja kwalifikowana jako instalacja odnawialnego źródła energii a urządzenie infrastruktury technicznej}

Pod pojęciem instalacji odnawialnego źródła energii należy rozumieć instalację stanowiącą wyodrębniony zespół urządzeń służących do wytwarzania energii opisanych przez dane techniczne i handlowe, w których energia jest wytwarzana z odnawialnych źródeł energii ${ }^{6}$, czyli z odnawialnych, niekopalnych źródeł energii obejmujących energię wiatru, energię promieniowania słonecznego, energię aerotermalną, energię geotermalną, energię hydrotermalną, hydroenergię, energię fal, prądów i pływów morskich, energię otrzymywaną z biomasy, biogazu, biogazu rolniczego oraz z biopłynów ${ }^{7}$. Instalacją odnawialnego źródła energii jest również instalacja stanowiąca wyodrębniony zespół obiektów budowlanych i urzą-

\footnotetext{
3 Por. art. 61 ust. 3 u.p.z.p. w brzmieniu obowiązującym do dnia 29 sierpnia 2019 roku.

4 Dz.U. z 2020 r. poz. 261 ze zm. (dalej: u.o.z.e.).

5 Zob. uzasadnienie projektu u.o.z.e.

${ }^{6}$ Zob. art. 2 pkt 13 lit. a u.o.z.e.

7 Por. art. 2 pkt 22 u.o.z.e.
} 
dzeń stanowiących całość techniczno-użytkową służący do wytwarzania biogazu rolniczego ${ }^{8}$. Podkreślenia przy tym wymaga, że instalację odnawialnego źródła energii stanowi także, połączony ze wskazanym powyżej zespołem urządzeń bądź obiektów budowlanych i urządzeń, magazyn energii ${ }^{9}$, w tym magazyn biogazu rolniczego ${ }^{10}$. Oznacza to, że kategoria instalacji odnawialnego źródła energii tworzy szeroką, a jednocześnie dość zróżnicowaną kategorię przedsięwzięć, których realizacja może wiązać się z koniecznością uzyskania decyzji o warunkach zabudowy. Inwestycję tę zasadniczo tworzy zespół urządzeń, ale w jej skład mogą wchodzić również, jeśli razem ze wskazanymi urządzeniami są całością techniczno-użytkową, obiekty budowlane ${ }^{11}$.

Mając na uwadze powyższe, wskazać należy, że zasadnicze znaczenie w kontekście wykładni przepisów u.p.z.p. ma możliwość identyfikowania instalacji odnawialnego źródła energii jako urządzenia infrastruktury technicznej. Brak definicji tego pojęcia w przepisach u.p.z.p. powoduje, iż niezbędne jest sięganie do przepisów innych ustaw i dokonywanie stosownej wykładni tego terminu. Jak wskazuje się $\mathrm{w}$ orzecznictwie sądowoadministracyjnym, zakres stosowania zawartej w art. 143 ust. 2 ustawy z dnia 21 sierpnia 1997 roku o gospodarce nieruchomościami $^{12}$ definicji urządzenia infrastruktury technicznej nie ogranicza się wyłącznie do instytucji opłat adiacenckich i jest oderwany od kwestii uzbrojenia terenu, a wykładnia użytego w niej pojęcia urządzenia elektrycznego wymaga zastosowania między innymi wykładni dynamicznej uwzględniającej okoliczność, że następuje ewolucja techniczna i technologiczna urządzeń elektrycznych i coraz większy procent energii jest wytwarzany ze źródeł odnawialnych ${ }^{13}$. W wyrokach sądów administracyjnych podnosi się zatem, że urządzenia infrastruktury technicznej to przewody lub urządzenia techniczne stosowane do wytwarzania, przetwarzania, przesyłania, magazynowania, dystrybucji oraz użytkowania energii elektrycznej, a pojęcie infrastruktury nie ogranicza się jedynie do urządzeń służących do przesyłu energii elektrycznej, ale także obejmuje urządzenia, które służą do jej wytwarzania, a w związku z tym uzasadnione jest zaliczanie do tej katego-

8 Zob. art. 2 pkt 13 lit. b u.o.z.e.

9 Zob. art. 2 pkt 17 u.o.z.e., w którym wskazano, że pod pojęciem magazynu energii należy rozumieć wyodrębnione urządzenie lub zespół urządzeń służących do przechowywania energii w dowolnej postaci, niepowodujących emisji, będących obciążeniem dla środowiska w sposób pozwalający co najmniej na jej częściowe odzyskanie.

10 Por. art. 2 pkt 13 in fine u.o.z.e.

11 Definicja obiektu budowlanego została ujęta w art. 3 pkt 1 ustawy z dnia 7 lipca 1994 roku Prawo budowlane, Dz.U. z 2019 r. poz. 1186 ze zm. (dalej: pr.bud.).

12 Zgodnie z przywołanym art. 143 ust. 2 ustawy z dnia 21 sierpnia 1997 roku o gospodarce nieruchomościami, Dz.U. z 2020 r. poz. 65 ze zm. (dalej: u.g.n.), przez budowę urządzeń infrastruktury technicznej rozumie się budowę drogi oraz wybudowanie pod ziemią, na ziemi albo nad ziemią przewodów lub urządzeń wodociągowych, kanalizacyjnych, ciepłowniczych, elektrycznych, gazowych i telekomunikacyjnych.

13 Zob. wyrok NSA z dnia 27 września 2017, II OSK 158/16, LEX 2382975. 
rii poszczególnych rodzajów instalacji odnawialnych źródeł energii ${ }^{14}$. W orzecznictwie sądowoadministracyjnym prezentowany jest również pogląd przeciwny, zgodnie z którym zaliczenie przez prawodawcę poszczególnych rodzajów instalacji odnawialnych źródeł energii do zabudowy przemysłowej wyłącza możliwość kwalifikowania ich jako urządzeń infrastruktury technicznej, o których mowa w art. 61 ust. 3 u.p.z.p. ${ }^{15}$ Wydaje się jednak, iż na aprobatę zasługuje stanowisko, zgodnie z którym uzasadnione jest kwalifikowanie poszczególnych rodzajów instalacji odnawialnych źródeł energii jako (wskazanych w art. 61 ust. 3 u.p.z.p.) urządzeń infrastruktury technicznej, gdyż pozostaje ono w zgodzie w wynikami wykładni przedmiotowego tekstu prawnego przeprowadzonej z uwzględnieniem zasad tak zwanej derywacyjnej koncepcji wykładni prawa ${ }^{16}$.

\section{Przesłanki wydania decyzji o warunkach zabudowy dla inwestycji kwalifikowanej jako instalacja odnawialnego źródła energii}

Zgodnie z regulacją ogólną ujętą w art. 61 ust. 1 u.p.z.p., wydanie decyzji o warunkach zabudowy - co do zasady - możliwe jest w przypadku łącznego spełnienia wskazanych poniżej pięciu przesłanek: (pkt 1) co najmniej jedna działka sąsiednia, dostępna z tej samej drogi publicznej, jest zabudowana w sposób pozwalający na określenie wymagań dotyczących nowej zabudowy w zakresie kontynuacji funkcji, parametrów, cech i wskaźników kształtowania zabudowy oraz zagospodarowania terenu, w tym gabarytów i formy architektonicznej obiektów budowlanych, linii zabudowy oraz intensywności wykorzystania terenu; (pkt 2) teren ma dostęp do drogi publicznej; (pkt 3) istniejące lub projektowane uzbrojenie terenu jest wystarczające dla zamierzenia budowlanego; (pkt 4) teren nie wymaga uzyskania zgody na zmianę przeznaczenia gruntów rolnych i leśnych na cele nierolnicze i nieleśne albo jest objęty zgodą uzyskaną przy sporządzaniu miejscowych planów, które utraciły moc na podstawie art. 67 ustawy z dnia 7 lipca 1994 roku o zagospodarowaniu przestrzennym ${ }^{17}$; (pkt 5) decyzja jest zgodna

14 Zob. wyroki NSA: z dnia 21 czerwca 2017 roku, II OSK 2637/15, LEX 2323043; z dnia 20 grudnia 2016 roku, II OSK 798/15, LEX 2248203; z dnia 12 stycznia 2016 roku, II OSK 1070/14, LEX 2033928; z dnia 4 lutego 2014 roku, II OSK 2129/12, LEX 1450885; z dnia 13 listopada 2012 roku, II OSK 762/12, LEX 1291979.

15 Zob. wyroki NSA: z dnia 12 stycznia 2018 roku, II OSK 794/16, LEX 2464426; z dnia 5 kwietnia 2017 roku, II OSK 2022/15, LEX 2316288.

16 Wykładni tej dokonała J. Dropińska-Bysiek, Lokalizacja farm fotowoltaicznych na obszarach nieobjętych ustaleniami miejscowego planu zagospodarowania przestrzennego, Kraków 2019, s. 256 n., niepublikowana.

17 Dz.U. z 1999 r. Nr 15, poz. 139 ze zm. (dalej: u.z.p.). 
z przepisami odrębnymi. Nadto, jak wynika z regulacji art. 56 w związku z art. 64 ust. 1 u.p.z.p., nie można odmówić ustalenia warunków zabudowy, jeżeli zamierzenie inwestycyjne jest zgodne z przepisami odrębnymi, a przepis art. 1 ust. 2 przedmiotowej ustawy nie może stanowić wyłącznej podstawy odmowy określenia warunków zabudowy i zagospodarowania terenu.

Ustawodawca przewidział jednak wyjątki od powyższej zasady, wskazując przypadki, w których wydanie decyzji o warunkach zabudowy dopuszczalne jest pomimo niespełnienia jednej lub kilku z przesłanek określonych w art. 61 ust. 1 u.p.z.p. ${ }^{18}$ Jeden $z$ takich przypadków został ujęty w art. 61 ust. 3 u.p.z.p. Zgodnie z jego regulacją przepisów art. 61 ust. 1 pkt 1 i 2 u.p.z.p. nie stosuje się między innymi do instalacji odnawialnego źródła energii w rozumieniu art. 2 pkt 13 u.o.z.e., a w związku z tym wydanie przedmiotowej decyzji lokalizacyjnej dla takich przedsięwzięć nie jest determinowane istnieniem tak zwanego dobrego sąsiedztwa oraz dostępu do drogi publicznej.

Powyższe oznacza, że decyzja o warunkach zabudowy dla inwestycji kwalifikowanej jako instalacja odnawialnego źródła energii może być wydana pomimo braku tak zwanego dobrego sąsiedztwa i/lub dostępu terenu planowanej inwestycji do drogi publicznej. Wyjaśnienia przy tym wymaga, że — co do zasady — tak zwane dobre sąsiedztwo to dostosowanie planowanej zabudowy do oznaczonych cech zagospodarowania terenu sąsiedniego. Jako cel tej zasady podnosi się w szczególności stworzenie czytelnego układu odniesienia, jakim jest stan istniejącej zabudowy, a w konsekwencji — zachowanie harmonii architektonicznej oraz funkcjonalnego charakteru określonego obszaru ${ }^{19}$. Dobre sąsiedztwo należy postrzegać zatem jako takie zagospodarowanie terenu, którego funkcje, a także parametry i cechy istniejącej zabudowy, mogą tworzyć harmonijną całość z inwestycją objętą wnioskiem o ustalenie warunków zabudowy ${ }^{20}$. Dostęp zaś do drogi publicznej ${ }^{21}$, przy czym taką są drogi krajowe, wojewódzkie, powiatowe oraz gminne, oznacza bezpośredni dostęp do tej drogi albo dostęp do niej przez drogę wewnętrzną lub przez ustanowienie odpowiedniej służebności drogowej ${ }^{22}$. Podkreślić trzeba przy tym, że dostęp terenu planowanej inwestycji do drogi publicznej powinien być legalny, co oznacza, że prawo do korzystania z niego musi wynikać wprost z przepisu prawa, czynności prawnej, orzeczenia sądowego lub administracyjnego ${ }^{23}$.

18 Zob. art. 61 ust. 2, 3 i 4 u.p.z.p.

19 Tak T. Bąkowski, [w:] W. Szwajdler, T. Bąkowski, Proces inwestycyjno-budowlany. Zagadnienia administracyjno-prawne, Torun 2004, s. 91.

${ }^{20}$ Szerzej na temat wskazanej w art. 61 ust. 1 pkt 1 u.p.z.p. przesłanki wydania decyzji o warunkach zabudowy zob. K. Małysa-Sulińska, Administracyjnoprawne aspekty inwestycji budowlanych, Warszawa 2012, s. 104 n.

21 Droga publiczna została zdefiniowana w art. 1 ustawy z dnia 21 marca 1985 roku o drogach publicznych, Dz.U. z 2020 r. poz. 470 (dalej: u.d.p.).

22 Zob. art. 2 pkt 14 u.p.z.p.

${ }^{23}$ Szerzej na temat wskazanej w art. 61 ust. 1 pkt 2 u.p.z.p. przesłanki wydania decyzji o warunkach zabudowy zob. K. Małysa-Sulińska, op. cit., s. 106 n. 


\section{Uzbrojenie terenu a możliwość wydania decyzji o warunkach zabudowy dla inwestycji kwalifikowanej jako instalacja odnawialnego źródła energii}

Jak wskazano, wydanie decyzji o warunkach zabudowy dla inwestycji kwalifikowanej jako instalacja odnawialnego źródła energii determinowane jest odpowiednim uzbrojeniem terenu planowanej inwestycji. Zgodnie z art. 2 pkt 13 u.p.z.p., pod pojęciem uzbrojenia terenu należy rozumieć drogi, obiekty budowlane, urządzenia i przewody, o których mowa w art. 143 ust. 2 u.g.n., czyli również — wybudowanie pod ziemią, na ziemi albo nad ziemią — przewody lub urządzenia wodociągowe, kanalizacyjne, ciepłownicze, elektryczne, gazowe i telekomunikacyjne.

Jak wynika z regulacji art. 61 ust. 1 pkt 3 u.p.z.p., zasadą jest realizacja inwestycji na terenie uzbrojonym, przy czym, zgodnie z brzmieniem art. 61 ust. 5 u.p.z.p., dopuszczalne jest wydanie decyzji o warunkach zabudowy, jeżeli wykonanie uzbrojenia terenu zostanie zagwarantowane w drodze umowy zawartej między właściwą jednostką organizacyjną a inwestorem. Celem regulacji ujętej w art. 61 ust. 1 pkt 3 u.p.z.p. nie jest zatem uzależnienie wydania decyzji lokalizacyjnej od faktycznego istnienia uzbrojenia terenu, ale - jak wskazuje się w orzecznictwie sądowoadministracyjnym - zagwarantowanie, że powstanie stosowne uzbrojenie umożliwiające prawidłowe korzystanie z obiektów budowlanych. Jeśli zatem uzbrojenie terenu nie zostało jeszcze zrealizowane, to umieszczenie na obszarze inwestycji właściwych urządzeń musi zostać zagwarantowane w drodze umowy zawartej pomiędzy inwestorem a gestorem sieci, czyli przedsiębiorstwem zajmującym się dostarczaniem odpowiednich usług ${ }^{24}$. Z regulacji art. 61 ust. 1 pkt $3 \mathrm{w}$ związku z art. 61 ust. 5 u.p.z.p. wywodzić należy jednak wyłącznie spoczywający na inwestorze obowiązek złożenia zapewnienia wykonania uzbrojenia terenu na potrzeby planowanej inwestycji. Zgodnie z poglądem już ugruntowanym w judykaturze, zapewnienie w drodze umowy, że powstanie stosowne uzbrojenie terenu nie oznacza obowiązku legitymowania się przez inwestora taką umową już w momencie starania się o wydanie decyzji o warunkach zabudowy. Wystarczające w tym zakresie jest wykazanie przez inwestora, że taka umowa w przyszłości zostanie zawarta poprzez przedłożenie dokumentu wydanego przez uprawnioną jednostkę świadczącą usługi komunalne według przepisów ustawy z dnia 20 grudnia 1996 roku o gospodarce komunalnej ${ }^{25}$, w którym uzgod-

24 Por. wyroki WSA: w Warszawie z dnia 23 stycznia 2006 roku, IV SA/Wa 1847/05, LEX 196465; z dnia 4 grudnia 2008 roku, IV SA/Wa 1361/08, LEX 533147; w Krakowie z dnia 15 maja 2009 roku, II SA/Kr 431/09, LEX 562862; we Wrocławiu z dnia 28 sierpnia 2009 roku, II SA/Wr 251/09, LEX 553289; w Szczecinie z dnia 24 maja 2018 roku, LEX 2525778.

25 Dz.U. z 2019 r. poz. 712 ze zm. 
niono planowane uzbrojenie terenu inwestycji oraz wskazano docelowe rozwiązania $\mathrm{w}$ zakresie uzbrojenia gruntu ${ }^{26}$. Organ właściwy w przedmiocie wydania decyzji lokalizacyjnej powinien więc zażądać od inwestora przedłożenia „dokumentu w rodzaju promesy", z ewentualnym projektem danej umowy ${ }^{27}$.

Na podstawie przedłożonych dokumentów, a w szczególności parametrów inwestycji wskazanych we wniosku o ustalenie warunków zabudowy, organ właściwy w przedmiocie wydania decyzji lokalizacyjnej powinien ustalić, czy uzbrojenie terenu jest wystarczające na potrzeby planowanego zamierzenia budowlanego ${ }^{28}$. W tym celu, mając na uwadze charakterystykę inwestycji obejmującą określenie zapotrzebowania $\mathrm{w}$ zakresie infrastruktury technicznej, wskazany organ winien oszacować zapotrzebowanie na media, jakie będzie generować planowana inwestycja ${ }^{29}$.

\section{Przeznaczenie gruntów rolnych i leśnych a możliwość wydania decyzji o warunkach zabudowy dla inwestycji kwalifikowanej jako instalacja odnawialnego źródła energii}

Kolejną przesłanką determinującą wydanie decyzji o warunkach zabudowy dla inwestycji kwalifikowanej jako instalacja odnawialnego źródła energii jest przeznaczenie gruntów na cele nierolnicze i nieleśne. Mając to na względzie, podnieść należy, że ustawodawca wyróżnia dwie kategorie, zdefiniowanych w przepisach ustawy $z$ dnia 3 lutego 1995 roku o ochronie gruntów rolnych i leśnych ${ }^{30}$, gruntów rolnych ${ }^{31}$ i leśnych ${ }^{32}$, a to takie, dla których nie jest wymagane uzyskanie zgody na zmianę przeznaczenia na cele nierolnicze i nieleśne oraz takie, dla których uzyskanie takiej zgody jest konieczne przed określeniem warunków zabudowy i zagospodarowania

26 Zob. wyroki WSA: w Łodzi z dnia 15 września 2016 roku, II SA/Łd 253/16, LEX 2154441; z dnia 15 września 2016 roku, II SA/Łd 278/16, LEX 2154453. Por. też wyroki WSA: w Warszawie z dnia 23 stycznia 2006 roku, IV SA/Wa 1847/05, LEX 196465; z dnia 15 kwietnia 2008 roku, IV SA/Wa 2480/07, LEX 519041; z dnia 4 grudnia 2008 roku, IV SA/Wa 1361/08, LEX 533147; we Wrocławiu z dnia 28 sierpnia 2009 roku, II SA/Wr 251/09, LEX 553289; w Krakowie z dnia 7 grudnia $2011 \mathrm{roku}$, II SA/Kr 1348/11, LEX 1152796.

27 Zob. wyrok WSA w Warszawie z dnia 23 stycznia 2006 roku, IV SA/Wa 1847/05, LEX 196465.

28 Zob. wyrok WSA w Poznaniu z dnia 6 października 2009 roku, II SA/Po 744/08, LEX 573831.

${ }^{29}$ Szerzej na temat przesłanki wydania decyzji lokalizacyjnej, o której mowa w art. 61 ust. 1 pkt 3 u.p.z.p. zob. K. Małysa-Sulińska, op. cit., s. 108 n.

30 Dz.U. z 2017 r. poz. 1161 (dalej: u.o.g.r.l.).

31 Wyliczenie gruntów rolnych ujęto w art. 2 ust. 1 u.o.g.r.l. Zob. też art. 2 ust. 3 u.o.g.r.l.

32 Wyliczenie gruntów rolnych ujęto w art. 2 ust. 2 u.o.g.r.l. 
terenu. Dopuszczalne jest zatem wydanie decyzji o warunkach zabudowy zarówno dla gruntów, które nie są kwalifikowane jako grunty rolne lub leśne, jak i wszystkich gruntów rolnych stanowiących użytki rolne, które są położone w granicach administracyjnych miast ${ }^{33}$, a nadto - położonych poza granicami administracyjnymi miast - gruntów rolnych klasy IV, IVa, IVb, V, VI, VIz lub gruntów rolnych o nieoznaczonej klasie. Wydanie decyzji o warunkach zabudowy jest dopuszczalne także dla — położonych poza granicami administracyjnymi miast — gruntów rolnych klasy I, II, III, IIIa i IIIb, ale tylko wówczas, gdy zachodzą łącznie przesłanki wskazane w art. 7 ust. 2a u.o.g.r.l. Oznacza to, że określenie warunków zabudowy i zagospodarowania terenu dla takich gruntów jest możliwe, gdy: (1) co najmniej połowa powierzchni każdej zwartej części gruntu zawiera się w obszarze zwartej zabudowy, przy czym, jak wskazano w art. 4 pkt 30 u.o.g.r.l., przez obszar zwartej zabudowy rozumieć należy obszar wyznaczony przez obwiednię prowadzoną w odległości 50 metrów od zewnętrznych krawędzi skrajnych budynków tworzących zwartą zabudowę $e^{34}$ lub po zewnętrznych granicach działek, na których położone są te budynki, jeśli ich odległość od tych granic jest mniejsza niż 50 metrów; (2) położone są w odległości nie większej niż 50 metrów od granicy najbliższej działki budowlanej w rozumieniu przepisów u.g.n. ${ }^{35}$; (3) położone są w odległości nie większej niż 50 metrów od drogi publicznej w rozumieniu przepisów u.d.p.; (4) ich powierzchnia nie przekracza 0,5 hektara, bez względu na to, czy tworzą jedną całość, czy kilka odrębnych części.

Zgodnie z rozwiązaniem przyjętym przez ustawodawcę dla gruntów wymagających uzyskania zgody na zmianę przeznaczenia na cele nierolnicze i nieleśne decyzję o warunkach zabudowy można wydać wówczas, gdy planowane przedsięwzięcie jest zgodne z rolnym lub leśnym przeznaczeniem terenu. To zaś oznacza, że realizacja takiego przedsięwzięcia nie może wiązać się ze zmianą jego przeznaczenia, a jedynie ma służyć kontynuacji celu, na jaki teren jest przeznaczony, pogłębieniu posiadanej przez niego funkcji ${ }^{36}$. Mając to na względzie, wskazać należy, że realizacja inwestycji kwalifikowanej jako instalacja odnawialnego źródła energii - co do zasady - wiąże się ze zmianą przeznaczenia gruntu na cel nierolniczy i nieleśny, a w związku z tym inwestycji takiej nie można klasyfikować jako przedsięwzięcia zgodnego z rolnym lub leśnym przeznaczeniem terenu. Nie można jednak wykluczyć odmiennych ustaleń w powyższym zakresie, a to przykładowo, gdy instalacja odnawialnego źródła energii jest realizowana w ramach gospodarstwa rolnego, a wytworzona energia ma służyć wyłącznie produkcji rolniczej oraz przetwórstwu rolno-spożywczemu.

33 Por. art. 10a u.o.g.r.1.

34 Definicja zwartej zabudowy została ujęta w art. 4 pkt 29 u.o.g.r.l.

35 Definicja działki budowlanej została ujęta w art. 4 pkt 3a u.g.n.

36 Zob. wyroki WSA: w Warszawie z dnia 1 czerwca 2007 roku, IV SA/Wa 598/07, LEX 340817; z dnia 11 sierpnia 2009 roku, IV SA/Wa 697/09, LEX 553492. 
Decyzja o warunkach zabudowy może być wydana dla gruntów rolnych bądź leśnych wszystkich kategorii również wówczas, gdy teren planowanej inwestycji został objęty zgodą na zmianę przeznaczenia na cele nierolnicze i nieleśne uzyskaną przy sporządzaniu planu miejscowego, który obowiązywał w dniu 1 stycznia 1995 roku, a utracił moc obowiązującą na podstawie art. 67 u.z.p. ${ }^{37}$, a zgoda ta została „skonsumowana" poprzez wprowadzenie adekwatnych ustaleń do miejscowego planu zagospodarowania przestrzennego. Podkreślenia wymaga przy tym, że okoliczność wydania, w odniesieniu do terenu planowanej inwestycji, decyzji wyrażającej zgodę na zmianę przeznaczenia gruntu na cele nierolnicze i nieleśne ma drugorzędne znaczenie, gdyż rozstrzygające znaczenie w tym zakresie mają ustalenia miejscowego planu zagospodarowania przestrzennego, o którym mowa powyżej. Decyzja o zgodzie na zmianę przeznaczenia terenu na cele nierolnicze i nieleśne nie dokonuje bowiem zmiany przeznaczenia tego gruntu, a to dlatego, że warunkiem nierolniczego i nieleśnego wykorzystania gruntów wskazanych w art. 7 ust. 2 u.o.g.r.l. jest — co do zasady — wejście w życie planu miejscowego określającego przeznaczenie przedmiotowego terenu jako nierolnicze i nieleśne ${ }^{38}$. Oznacza to, iż z samej okoliczności wydania zgody właściwego organu na zmianę przeznaczenia terenu na cele nierolnicze i nieleśne, której nie towarzyszyło wprowadzenie stosownych ustaleń do miejscowego planu zagospodarowania przestrzennego, nie można wywodzić, że zachodzi przesłanka wydania decyzji o warunkach zabudowy, o której mowa w art. 61 ust. 1 pkt 4 u.p.z.p. ${ }^{39}$

\section{Przepisy odrębne a możliwość wydania decyzji o warunkach zabudowy dla inwestycji kwalifikowanej jako instalacja odnawialnego źródła energii}

Wydanie decyzji o warunkach zabudowy dla inwestycji kwalifikowanej jako instalacja odnawialnego źródła energii determinowane jest również zgodnością de-

37 Zgodnie z wolą ustawodawcy ustalenie warunków zabudowy i zagospodarowania terenu na cel nierolny i nieleśny dla gruntu rolnego lub leśnego nie jest jednak dopuszczalne, jeśli przedmiotowa zgoda została udzielona w związku ze sporządzaniem miejscowego planu zagospodarowania przestrzennego, który utracił moc w innych okolicznościach niż wskazane w art. 67 u.z.p., a to na przykład w związku ze stwierdzeniem jego nieważności (por. K. Jaroszyński, A. Szmytt, Ł. Złakowski, Planowanie i zagospodarowanie przestrzenne. Komentarz, Warszawa 2011, s. 526).

38 Szerzej na temat przesłanki wydania decyzji lokalizacyjnej, o której mowa w art. 61 ust. 1 pkt 4 u.p.z.p., zob. K. Małysa-Sulińska, op. cit., s. 64 n.

39 Zob. uchwała NSA z dnia 29 listopada 2010 roku, II OPS 1/10, LEX 621577. Por. też wyroki WSA: w Warszawie z dnia 16 kwietnia 2019 roku, IV SA/Wa 468/19, LEX 2689556; w Białymstoku z dnia 4 lipca 2019 roku, II SA/Bk 285/19, LEX 2700073. 
cyzji lokalizacyjnej z przepisami, co wynika wprost z brzmienia art. 61 ust. 1 pkt 5 u.p.z.p., przy czym dopełnienie tej regulacji ujęte jest w art. 56 u.p.z.p..$^{40}$, który to przepis stosuje się odpowiednio do decyzji o warunkach zabudowy ${ }^{41}$. Omawiana przesłanka wydania decyzji o warunkach zabudowy jest zatem spełniona, jeśli można stwierdzić, iż realizacja planowanej inwestycji nie jest sprzeczna ${ }^{42} \mathrm{z}$ przepisami prawa powszechnie obowiązującego ${ }^{43}$, które ujęte są zarówno w ustawie z dnia 27 marca 2003 roku o planowaniu i zagospodarowaniu przestrzennym, jak i w innych aktach normatywnych ${ }^{44}$, a wyjątkiem $w$ tym zakresie jest wyłączenie regulacja art. 1 ust. 2 u.p.z.p., w którym zawarto zasady planowania i zagospodarowania przestrzennego ${ }^{45}$. Zauważenia wymaga przy tym, że klauzule generalne ujęte we wskazanym przepisie mogą mieć wpływ na rozstrzygnięcie w przedmiocie określenia warunków zabudowy i zagospodarowania terenu wyłącznie wówczas, gdy zostały skonkretyzowane przez przepis nakładający expressis verbis konkretne ograniczenia ${ }^{46}$. Nie ma bowiem możliwości dokonywania rozszerzającej interpretacji klauzul generalnych zawartych w art. 1 ust. 2 u.p.z.p. To zaś oznacza, że odmowa ustalenia warunków zabudowy może mieć oparcie wyłącznie w wyraźnej sprzeczności zamierzenia inwestycyjnego z przepisem nakładającym wprost ogra-

40 Zgodnie z brzmieniem przywołanego przepisu nie można odmówić określenia warunków zabudowy i zagospodarowania terenu, jeżeli zamierzenie inwestycyjne jest zgodne z przepisami odrębnymi, a przepis art. 1 ust. 2 u.p.z.p. nie może stanowić wyłącznej podstawy przedmiotowej odmowy.

41 Zob. art. 64 ust. 1 u.p.z.p.

42 Por. K. Jaroszyński, A. Szmytt, Ł. Złakowski, op. cit., s. 469 n. Por. także wyroki, w których wskazano, że jeśli żaden przepis prawa nie sprzeciwia się zamierzeniu inwestycyjnemu, to organ ma obowiązek wydać pozytywną decyzję stosownie do art. 56 u.p.z.p. (zob. wyroki: WSA w Gliwicach z dnia 20 sierpnia 2008 roku, II SA/Gl 414/08, LEX 519014; WSA w Gorzowie Wielkopolskim z dnia 18 listopada 2009 roku, II SA/Go 441/09, LEX 589111).

43 Punktu odniesienia nie mogą więc stanowić przepisy, które nie mają charakteru przepisów powszechnie obowiązujących, a także przepisy, które nie zaczęły jeszcze obowiązywać (por. wyrok WSA w Lublinie z dnia 29 stycznia 2009 roku, II SA/Lu 603/08, LEX 519833).

${ }^{44} \mathrm{~W}$ literaturze podnosi się bowiem, że choć w art. 56 u.p.z.p. użyto terminu „przepisy odrębne”, regulacja ta odnosi się również do przepisów u.p.z.p. (tak K. Jaroszyński, A. Szmytt, Ł. Złakowski, op. cit., s. 470).

45 Zauważenia wymaga, że katalog zasad ujętych w art. 1 ust. 2 u.p.z.p. obowiązuje organy w procesie kształtowania i prowadzenia polityki przestrzennej. Zasady te, z uwagi na zbytnią ogólność, nie mogą natomiast stanowić materialnoprawnej podstawy do wydawania decyzji administracyjnych, a to dlatego, że mają inny charakter prawny niż przepisy o charakterze szczególnym, w tym regulujące ustalanie warunków zabudowy (por. wyrok WSA w Krakowie z dnia 21 października 2008 roku, II SA/Kr 723/08, LEX 499852). Por. również wyrok WSA w Poznaniu z dnia 18 września 2007, II SA/Po 245/07, LEX 372431, w którym wskazano, że zasada uwzględniania przez organy administracji w planowaniu i zagospodarowaniu przestrzennym wymagań ładu przestrzennego, w tym urbanistyki i architektury, ma charakter klauzuli generalnej, a jednocześnie bezpośrednio nie może stanowić dla inwestora żadnych ograniczeń w zakresie dopuszczalnego sposobu zabudowy i zagospodarowania terenu.

46 Zob. wyrok WSA w Poznaniu z dnia 12 maja 2010 roku, IV SA/Po 103/10, LEX 675118. 
niczenia ${ }^{47}$. Analiza aktów prawa powszechnie obowiązującego może wykazać, że projektowana zmiana zagospodarowania terenu jest niedopuszczalna, przy czym w takim przypadku organ jest zobligowany do przywołania konkretnego przepisu prawa ${ }^{48}$, którego dyspozycja jest naruszona, a także wykazania zakresu tego naruszenia $^{49}$.

\section{Podsumowanie i wnioski}

Przepis art. 61 ust. 3 u.p.z.p. w brzmieniu obowiązującym od dnia 29 sierpnia 2019 roku nie pozostawia wątpliwości, że wydanie decyzji o warunkach zabudowy dla inwestycji kwalifikowanej jako instalacja odnawialnego źródła energii następuje z pominięciem zasady dobrego sąsiedztwa oraz dostępu do drogi publicznej. W przywołanym przepisie wskazano wprost, że przepisów art. 61 ust. 1 pkt 1 i 2 u.p.z.p. nie stosuje się do instalacji odnawialnego źródła energii w rozumieniu u.o.z.e. Oznacza to, że wydanie tej decyzji determinowane jest spełnieniem wyłącznie trzech, a nie pięciu, jak zasadniczo ma to miejsce w przypadku wydawania decyzji o warunkach zabudowy, przesłanek, o których mowa w art. 61 ust. 1 u.p.z.p. Przedmiotowa decyzja lokalizacyjna wydawana jest zawsze wtedy, gdy istniejące lub projektowane uzbrojenie terenu jest wystarczające dla zamierzenia budowlanego, teren nie wymaga uzyskania zgody na zmianę przeznaczenia na cele nierolnicze i nieleśne albo jest objęty zgodą uzyskaną przy sporządzaniu planów miejscowych, które utraciły moc na podstawie art. 67 u.z.p., a rozstrzygnięcie pozostaje zgodne z obowiązującymi powszechnie przepisami prawa.

Mając na uwadze powyższe, wskazać należy, iż wyłączeniem, o którym mowa w art. 61 ust. 3 u.p.z.p., ustawodawca - obok instalacji odnawialnych źródeł energii — objął również urządzenia infrastruktury technicznej, przy czym te ostatnie zostały ujęte już w tekście pierwotnym przedmiotowego przepisu. Jednocześnie zauważenia wymaga, że w przepisach u.p.z.p. nie zawarto definicji pojęcia infrastruktury technicznej, co powoduje, że stosowanie regulacji art. 61 ust. 3 u.p.z.p.

47 Zob. wyroki WSA: w Warszawie z dnia 13 czerwca 2006 roku, IV SA/Wa 441/06, LEX 232973; w Lublinie z dnia 18 października 2007 roku, II SA/Lu 539/07, LEX 424673; w Krakowie z dnia 31 października 2008 roku, II SA/Kr 830/08, LEX 499881; w Poznaniu z dnia 12 maja 2010 roku, IV SA/Po 103/10, LEX 675118; we Wrocławiu z dnia 28 września 2010 roku, II SA/Wr 407/10, LEX 755591.

${ }^{48} \mathrm{Na}$ temat przepisów odrębnych, o których mowa w art. 61 ust. 1 pkt 5 u.p.z.p. zob. T. Bąkowski, Ustawa o planowaniu i zagospodarowaniu przestrzennym. Komentarz, Kraków 2004, s. 212-213; A. Despot-Mładanowicz, [w:] K. Buliński et al., Ustawa o planowaniu i zagospodarowaniu przestrzennym. Komentarz, Warszawa 2016, s. 627 n. Zob. również M. Szewczyk, [w:] Z. Leoński, M. Szewczyk, M. Kruś, Prawo zagospodarowania przestrzeni, Warszawa 2019, s. 396 n.

49 Por. wyroki WSA: w Gliwicach z dnia 20 sierpnia 2008 roku, II SA/Gl 414/08, LEX 519014; w Gorzowie Wielkopolskim z dnia 4 stycznia 2011 roku, II SA/Go 743/10, LEX 753145. 
wiąże się z koniecznością sięgania do przepisów innych ustaw w celu dokonania wykładni tego terminu. Konieczność zaś dokonywania wykładni pojęcia infrastruktury technicznej przyniosła skutek w postaci wykształcenia się dwóch przeciwstawnych linii orzeczniczych w zakresie możliwości kwalifikowania instalacji odnawialnych źródeł energii jako urządzeń infrastruktury technicznej.

Jak wskazano w uzasadnieniu projektu u.o.z.e., to właśnie wskazana tu rozbieżność judykatury, a także potrzeby procesu inwestycyjnego w branży odnawialnych źródeł energii spowodowały konieczność objęcia regulacją art. 61 ust. 3 u.p.z.p. również instalacji odnawialnych źródeł energii. W ocenie projektodawców wprowadzonej zmiany normatywnej nowe brzmienie art. 61 ust. 3 u.p.z.p. „potwierdza, że urząadzenia wytwarzające energię z odnawialnych źródeł nie stanowią urządzeń infrastruktury technicznej”. Mając to na względzie, wskazać należy, że choć wprowadzona nowelizacja art. 61 ust. 3 u.p.z.p. rozwiązuje niepewność przedsiębiorców inwestujących w instalacje odnawialnych źródeł energii, trudno ocenić ją pozytywnie. Wprowadzona zmiana normatywna wbrew twierdzeniom projektodawców nie jest potwierdzeniem, że instalacje odnawialnych źródeł energii nie są urządzeniami infrastruktury technicznej. Wyłączenie w przywołanym przepisie stosowania art. 61 ust. 1 pkt 1 i 2 u.p.z.p. do linii kolejowych, obiektów liniowych i urządzeń infrastruktury technicznej, a także instalacji odnawialnych źródeł energii w rozumieniu art. 2 pkt 13 u.o.z.e. nie oznacza, że zakres znaczeniowy pojęć w nim ujętych jest rozłączny. Tytułem przykładu wskazać należy, że linia kolejowa niewątpliwie jest obiektem liniowym, który ustawodawca — w art. 3 pkt 3a pr.bud. definiuje jako obiekt budowlany, którego charakterystycznym parametrem jest długość, wskazując jednocześnie, iż takim jest między innymi właśnie linia kolejowa. Jednocześnie wprowadzona zmiana nie rozwiązuje wątpliwości interpretacyjnych towarzyszących wykładni - użytego w art. 61 ust. 3 u.p.z.p. — terminu ,urządzenie infrastruktury technicznej”, gdyż w dalszym ciągu na gruncie przepisów u.p.z.p. nie jest on definiowany.

\section{Bibliografia}

Bąkowski T., Ustawa o planowaniu i zagospodarowaniu przestrzennym. Komentarz, Kraków 2004. Buliński K., Despot-Mładanowicz A., Filipowicz T., Kosicki A., Plucińska-Filipowicz A., Rypina M., Wincenciak M., Ustawa o planowaniu i zagospodarowaniu przestrzennym. Komentarz, red. M. Wierzbowski, A. Plucińska-Filipowicz, Warszawa 2016.

Dropińska-Bysiek J., Lokalizacja farm fotowoltaicznych na obszarach nieobjętych ustaleniami miejscowego planu zagospodarowania przestrzennego, Kraków 2019, niepublikowana.

Jaroszyński K., Szmytt A., Złakowski Ł., Planowanie i zagospodarowanie przestrzenne. Komentarz, red. Z. Niewiadomski, Warszawa 2011.

Leoński Z., Szewczyk M., Kruś M., Prawo zagospodarowania przestrzeni, Warszawa 2019.

Małysa-Sulińska K., Administracyjnoprawne aspekty inwestycji budowlanych, Warszawa 2012.

Szwajdler W., Bąkowski T., Proces inwestycyjno-budowlany. Zagadnienia administracyjno-prawne, Torun 2004.

Prawo 329, 2020

(C) for this edition by CNS 


\title{
Special rules of granting planning permission for installation qualified as installation of renewable sources of energy
}

\begin{abstract}
Summary
The subject matter of the article are special rules of granting planning permission for installation qualified as installation of renewable sources of energy. Conditions were presented, therefore, the satisfaction of which determines the granting of the location decision in question. It was also noted that the amendment, effective as of 29th August 2019, of Article 61.3 of the Act on Spatial Planning and Management which directly introduced references to installation of a renewable source of energy, basically did not change the binding regulations as regards the specification of land development and management conditions.
\end{abstract}

Keywords: installation of a renewable source of energy, technical infrastructure device, conditions for issuing planning consents. 